\title{
NILAI STRATEGIS KOMPETENSI PROFESSIONAL DAN KOMPETENSI PEDAGOGIK GURU DALAM PENINGKATAN HASIL UJIAN NASIONAL (Studi Kasus di Madrasah Ibtidaiyah (MI) Global Blotongan Kota Salatiga)
}

\author{
Abdul Syukur \\ Institut Agama Islam Negeri (IAIN) Salatiga \\ Syukurabdulsyukur36@yaboo.co.id
}

\begin{abstract}
This study aims to describe the strategic value of professional competence and pedagogical competence of teachers in improving the results of national examinations (UN). This study used a qualitative approach. Data were collected using a natural background (natural setting) as the data source directly. This research data collection method used interviews, observation, and documentation study. The results showed that: teacher competence, ethics and morale seen from strata taken adequate education, the development of creativity and innovation in average position. National exam performance in the past three years has shown that the results are far cry from satisfactory state yet they always reached 100\% success.
\end{abstract}

Keywords: Strategic Value, Professional Competence and Pedagogical Competence of Teachers, the Results of the National Exam (UN)

\begin{abstract}
Abstrak
Penelitian ini bertujuan untuk mengetabui gambaran nilai strategis kompetensi profesional dan kompetensi pedagogik guru dalam peningkatan hasil ujian nasional (UN). Penelitian ini menggunakan pendekatan kualitatif. Data yang dikumpulkan menggunakan latar alami (natural setting) sebagai sumber data langsung. metode pengumpulan data penelitian ini menggunakan wawancara, observasi, dan studi dokumentasi. Hasil penelitian ini menunjukkan bahwa: kompetensi guru,etos dan semangat kerja dilihat dari strata pendidikan yang ditempub cukup memadai, pengembangan kreatifitas maupun inovasi berada pada posisi sedang. Prestasi ujian nasional tiga tahun terabir menunjukkan hasil yang jaub dari menggembirakan meskipun selalu lulus $100 \%$.
\end{abstract}

Kata Kunci: Nilai Strategis, Kompetensi Professional dan Kompetensi

Pedagogik Guru, Hasil Ujian Nasional (UN)

Permalink/DOI: http://dx.doi.org/10.18326/infsl3.v9i2.515-536 


\section{Pendahuluan}

Sumber daya manusia (SDM) yang bermutu hanya dapat dihasilkan oleh pendidikan yang bermutu. Pendidikan bermutu sangat ditentukan diantaranya oleh adanya pendidik yang bermutu pula, karena pendidik sebagai agen pembelajaran dan pembaharuan untuk membudayakan manusia dalam mewujudkan tujuan pendidikan. Hakikat proses pendidikan adalah bantuan pendidik kepada peserta didik dalam bentuk bimbingan, arahan, pembelajaran, dan pelatihan yang dilakukan secara sadar dan terencana.Artinya,proses pengembangan manusia yang terdidik dan cerdas memerlukan pendidik yang mampu mengembangkan seluruh potensi peserta didik secara optimal melalui olah qolbu, olah cipta atau pikir, olah karsa, olah karya, olah rasa, dan bahkan olah raga.

\section{Landasan Teori}

\section{Pengertian Kompetensi}

Louise Moqvist (2003) sebagaimana dikutip oleh E. Mulyasa (2008:32) mengemukakan bahwa "competency has been defined in the light of actual circumstances relating to the individual and work. Sementara itu, dari Trainning Agency sebagaimana disampaikan Len Holmes (1992) menyebutkan bahwa : " A competence is a description of something which a person who works in a given occupational area should be able to do. It is a description of an action, behaviour or outcome which a person should be able to demonstrate" (Mohamad Uzer Usman,1995:121).

Dari kedua pendapat di atas, kiranya dapat ditarik benang merahnya bahwa yang dimaksudkan dengan kompetensi pada dasarnya merupakan gambaran tentang apa yang seyogyanya dapat dilakukan (be able to do) oleh seseorang dalam suatu pekerjaan, berupa kegiatan, perilaku dan hasil yang pada muaranya dapat ditampilkan atau ditunjukkan. Agar dapat melakukan (be able to do) sesuatu dalam pekerjaannya, tentu saja seseorang harus memiliki kemampuan (ability) dalam bentuk pengetahuan (knowledge), sikap (attitude) dan keterampilan (skill) yang sesuai dengan bidang pekerjaannya (Ibrahim Bafadhal,2009:59) 
Dalam perspektif kebijakan pendidikan nasional, pemerintah telah merumuskan empat jenis kompetensi guru sebagaimana tercantum dalam Penjelasan Peraturan Pemerintah No 19 Tahun 2005 tentang Standar Nasional Pendidikan dan ditindaklanjuti dalam Permendiknas No. 16 Tahun 2007 tentang Standar Kualifikasi Akademik dan Kompetensi Guru, maka kompetensi yang harus ada pada diri guru meliputi ;

1. Kompetensi pedagogik, yaitu merupakan kemampuan dalam pengelolaan peserta didik yang meliputi: pemahaman wawasan atau landasan kependidikan, pemahaman terhadap peserta didik, pengembangan kurikulum/ silabus, perancangan pembelajaran, pelaksanaan pembelajaran yang mendidik dan dialogis, evaluasi hasil belajar, dan pengembangan peserta didik untuk mengaktualisasikan berbagai potensi yang dimilikinya.

2. Kompetensi kepribadian, yaitu merupakan kemampuan kepribadian yang mantap,stabil, dewasa, arif dan bijaksana, berwibawa, berakhlak mulia,menjadi teladan bagi peserta didik dan masyarakat, mengevaluasi kinerja sendiri, dan mengembangkan diri secara berkelanjutan.

3. Kompetensi sosial, yaitu merupakan kemampuan pendidik sebagai bagian dari masyarakat untuk : berkomunikasi lisan dan tulisan, menggunakan teknologi komunikasi dan informasi secara fungsional, bergaul secara efektif dengan peserta didik, sesama pendidik, tenaga kependidikan, orangtua/wali peserta didik; dan bergaul secara santun dengan masyarakat sekitar.

4. Kompetensi professional, merupakan kemampuan penguasaan materi pembelajaran secara luas dan mendalam yang meliputi: konsep, struktur, dan metoda keilmuan/teknologi/seni yang menaungi/koheren dengan materi ajar, materi ajar yang ada dalam kurikulum sekolah; Hubungan konsep antar mata pelajaran terkait; Penerapan konsep-konsep keilmuan dalam kehidupan sehari-hari; dan Kompetisi secara profesional dalam konteks global dengan tetap melestarikan nilai dan budaya nasional. 


\section{Peran Guru Dalam Pembelajaran}

Semua orang meyakini bahwa guru memiliki peran yang sangat besar terhadap keberhasilan pembelajaran dan pendidikan pada umumnya. Menurut Sudarman Danim (2011:35-49) guru harus kreatif, professional dan menyenangkan dengan tetap memperhatikan posisinya sebagai berikut :

a. Guru Sebagai Pendidik

Guru adalah pendidik, yang menjadi tokoh, panutan dan identifikasi bagi para peserta didik dan lingkungannya. Oleh karena itu guru harus memiliki standar kualitas pribadi tertentu yang mencakup tanggungjawab, wibawa, mandiri dan disiplin.

b. Guru Sebagai Pengajar

Guru membantu peserta didik yang sedang berkembang untuk mempelajari yang belum diketahuinya, membentuk kompetensi, dan memahami materi standar yang dipelajari. Berkembangnya teknologi, khususnya teknologi informasi yang begitu pesat perkembangannya, belum mampu menggantikan peran dan fungsi guru, hanya sedikit menggeser atau mengubah fungsinya, itupun terjadi di kota-kota besar saja, ketika peserta didik memiliki berbagai sumber belajar di rumahnya(Abdul Majid,2010:27). Kegiatan belajar peserta didik dipengaruhi oleh berbagai faktor, seperti motivasi, kematangan, hubungan peserta didik dengan guru, kemampuan verbal, tingkat kebebasan, rasa aman, dan keterampilan guru dalam bekomunikasi. Jika faktorfaktor di atas dipenuhi, maka melalui pembelajaran peserta didik dapat belajar dengan baik.

c. Guru Sebagai Pembimbing

Guru dapat diibaratkan sebagai pembimbing perjalanan bagi anak didik baik fisik maupun mental, emosional, keatifitas, moral dan spiritual yang lebih dalam dan kompleks (Hamzah B. Uno,2011:83). Sebagai pembimbing, guru memerlukan kompetensi yang tinggi untuk melaksanakan hal-hal berikut.

1). Guru harus merencanakan tujuan dan mengidentifikasi kompetensi yang hendak dicapai. Tugas guru adalah 
menetapkan apa yang dimiliki oleh peserta didik sehubungan dengan latar belakang dan kemampuannya, serta kompetensi apa yang mereka perlukan untuk dipelajari dalam mencapai tujuan.

2). Guru harus melihat keterlibatan peserta didik dalam pembelajaran, dan yang paling penting bahwa peserta didik melaksanakan kegiatan belajar itu tidak hanya secara jasmaniah, melainkan mereka harus terlibat secara psikologis.

3). Guru harus memaknai kegiatan belajar, karena guru harus memberikan kehidupan dan arti terhadap kegiatan belajar. Boleh jadi pembelajaran direncanakan dengan baik, dilaksanakan secara tuntas; akan tetapi kurang relevan, kurang hidup, dan kurang bermakna.

4). Guru harus melaksanakan penilaian. Kegiatan ini hasilnya diharapkan dapat membawa manfaat terutama untuk memperbaiki kualitas pembelajaran.

\section{d. Guru Sebagai Pelatih}

Proses pendidikan dan pembelajaran memerlukan latihan keterampilan, baik intelektual maupun motorik, sehingga menuntut guru untuk bertindak sebagai pelatih (Oemar Hamalik,2010:93). Pelatihan yang dilakukan, di samping harus memperhatikan kompetensi dasar dan meteri standar, juga harus mampu memperhatikan perbedaan individual peserta didik, dan lingkungannya.

e. Guru Sebagai Penasihat

Guru adalah seorang penasehat bagi peserta didik, bahkan juga bagi orang tua, meskipun mereka tidak memiliki latihan khusus sebagai penasehat (Jejen Musfah,2011:69). Peserta didik senantiasa berhadapan dengan kebutuhan untuk membuat keputusan, dan dalam prosesnya akan lari kepada gurunya. Sebagai salah satu pendukung untuk suksesnya guru dalam melaksanakan perannya sebagai penasehat, maka guru perlu menguasai, memahami dan menghayati psikologi kepribadian dan ilmu kesehatan mental. 
f. Guru Sebagai Pembaharu

Prinsip modernisasi tidak hanya diwujudkan dalam bentuk buku-buku sebagai alat utama pendidikan, melainkan dalam semua rekaman tentang pengalaman manusia. Tugas guru adalah menerjemahkan kebijakan dan pengalaman yang berharga ke dalam istilah atau bahasa modern yang dapat diterima oleh peserta didik (E.Mulyasa,2003:64).

g. Guru Sebagai Model dan Teladan

Guru merupakan model atau teladan bagi peserta didik dan semua orang yang menganggap dia sebagai guru. Menjadi teladan merupakan sifat dasar kegiatan pembelajaran, dan ketika seorang guru tidak mau menerima ataupun menggunakannya secara konstruktif maka telah mengurangi keefektifan pembelajaran (Trianto,2011:45).

h. Guru Sebagai Pribadi

Sebagai individu yang berkiprah dalam pendidikan, guru harus memiliki kepribadian yang mencerminkan seorang pendidik. Tuntutan akan kepribadian sebagai pendidik kadang-kadang dirasakan lebih berat dibandingkan dengan profesi yang lain (Wina Sanjaya,2011:73). Sebagai pribadi yang hidup di tengahtengah masyarakat, guru perlu juga memiliki kemampuan untuk berbaur dengan masyarakat melalui berbagai kemampuannya. Keluwesan dalam bergaul menjadikannya mudah untuk diterima di tengah-tengah masyarakat. Karenanya, jika di masyarakat guru diamati dan dinilai oleh masyarakat; akan tetapi jika di sekolah guru diamati oleh peserta didik, teman sejawat dan atasan atau kepala.

i. Guru Sebagai Peneliti

Pembelajaran merupakan seni yang dalam pelaksanaannya memerlukan penyesuaian dan modivikasi dengan kondisi lingkungan (Dede Rosyada,2007:78). Untuk itu diperlukan berbagai penelitian, yang didalamnya melibatkan guru. Oleh karena itu, guru adalah seorang pencari atau peneliti. 
j. Guru Sebagai Pendorong Kreativitas

Kreatifitas merupakan hal yang sangat penting dalam pembelajaran, dan guru dituntut untuk mendemonstrasikan dan menunjukkan proses kreativitas tersebut (S.Nasution,2008:94). Sebagai orang yang kreatif, guru harus menyadari bahwa kreativitas merupakan hal yang universal dan oleh karenanya ditopang, dibimbing dan dibangkitkan oleh kesadaran itu

k. Guru Sebagai Pembangkit Pandangan

Mengemban fungsi ini, maka guru harus terampil dalam berkomunikasi dengan peserta didik di segala umur sehingga setiap langkah dari proses pendidikan yang dilangsungkannya mendukung peran ini (S.Nasution,2011:92).

1. Guru Sebagai Pekerja Rutin

Guru bekerja dengan keterampilan dan kebiasaan tertentu serta kegiatan rutin yang sangat diperlukan dan seringkali memberatkan(Wina Sanjaya,2011:59). Jika kegiatan tersebut tidak dikerjakan dengan baik, maka dapat mengurangi bahkan merusak keefektifan guru pada semua perannya.

m. Guru Sebagai Pemindah Kemah

Dalam setiap aspek, perkembangan aspek kepribadian memiliki ciri-ciri khusus sehubungan dengan tuntutan kenyataan yang efektif dilihat dari segi waktu dan tempat (Toto Taharuddin,2002:74). Ketika terjadi perubahan tuntutan terhadap cara berperilaku, peserta didik dan guru harus segera menyesuaikan dan memenuhi tuntutan baru, serta meninggalkan kebiasaan lama yang tidak lagi membantu pemenuhan kebutuhan.

n. Guru Sebagai Pembawa Cerita

Guru dengan menggunakan suaranya, memperbaiki kehidupan melalui puisi, dan berbagai cerita tentang manusia. Guru tidak takut menjadi alat untuk menyampaikan cerita-cerita tentang kehidupan, karena dia mengetahui sepenuhnya bahwa cerita itu sangat bermanfaat bagi manusia, dan dia berharap bisa menjadi pembawa cerita yang baik (Wina Sanjaya,2011:29). 
o. Guru Sebagai Aktor

Sebagai seorang aktor, guru melakukan penelitian tidak hanya terbatas pada materi yang harus ditransferkan, melainkan juga tentang kepribadian manusia sehingga mampu memahami respon-respon pendengarnya, dan merencanakan kembali pekerjaannya sehingga dapat dikontrol (Nana Sujana dan R.Ibrahim,2000:59).

p. Guru Sebagai Emansipator

Sebagai emansipator, guru harus mampu melihat sesuatu yang tersirat di samping yang tersurat, serta mencari kemungkinan pengembangannya. Yang demikian ini, karena guru paham bahwa pengalaman, pengakuan dan dorongan seringkali dapat membebaskan peserta didik dari self image yang tidak menyenangkan, kebodohan dan dari perasaan tertolak dan rendah diri.

q. Guru Sebagai Evaluator

Evaluasi atau penilaian merupakan aspek pembelajaran yang paling kompleks, karena melibatkan banyak latar belakang dan hubungan serta variable lain yang mempunyai arti apabila berhubungan dengan konteks yang hampir tidak mungkin dapat dipisahkan dengan setiap segi penilaian(Cony Semiawan,1982:19). Tidak ada pembelajaran tanpa penilaian, karena penilaian merupakan proses menetapkan kualitas hasil belajar, atau proses untuk menentukan tingkat pencapaian tujuan pembelajaran oleh peserta didik. Sebagai suatu proses, penilaian dilaksanakan dengan prinsip-prinsip dan teknik yang sesuai dan relevan.Mengingat kompleksnya proses penilaian, guru harus memiliki pengetahuan, keterampilan dan sikap yang memadai.

r. Guru Sebagai Pengawet

Untuk melaksanakan tugasnya sebagai pengawet terhadap apa yang telah dicapai sehingga manusia terdahulu, dikembangkanlah salah satu sarana pendidikan yang disebut dengan kurikulum, yang secara sederhana dapat diartikan sebagai program pembelajaran (Depdiknas. 2002:74). Dengan 
kurikulum, maka jaminan pengetahuan yang telah ditemukan dan disusun para pemikir pendidikan lebih kuat, meskipun dalam perkembangannya kurikulum harus fleksibel memungkinkan perubahan, dan memungkinkan guru mengembangkan kreativitasnya.

s. Guru Sebagai Kulminator

Guru adalah orang yang mengarahkan proses belajar secara bertahap dari awal hingga akhir (kulminasi). Dengan rancangannya, peserta didik akan melewati tahap kulminasi yang memungkinkan setiap peserta didik dapat mengetahui kemajuan belajarnya. Melalui rancangannya, guru mengembangkan tujuan yang akan dicapai dan akan dimunculkan dalam tahap kulminasi (H.A.R.Tilaar,1997:39).

\section{Metode Penelitian}

Jenis dan Sumber Data

Penelitian ini menggunakan pendekatan kualitatif. Penelitian kualitatif termasuk penelitian historis dan deskriptif yang tidak menggunakan model-model matematik, statistik atau komputer. Proses penelitian dimulai dengan menyusun asumsi dasar dan aturan berpikir yang akan digunakan dalam penelitian. Dalam penelitian kualitatif informasi yang dikumpulkan dan diolah harus tetap obyektif dan tidak dipengaruhi oleh pendapat peneliti sendiri. Metode pengumpulan data dalam penelitian ini menggunakan wawancara, observasi dan studi dokumentasi

\section{Analisis Hasil Penelitian}

Profil, Visi Dan Misi Madrasah Ibtidaiyah Ma'arif Global

Nama

Lembaga Pendiri

Akte Notaris Yayasan

Tahun Berdiri

Nomor Induk
Madrasah Ibtidaiyah Ma'arif Global (Islamic Global Elementary School Salatiga)

Lembaga Pendidikan Mararif NU Kota Salatiga

Joenues E. Maogimons SH. No. 103

1 Agustus 1966

083 
$\begin{array}{lll}\text { Nomor } & \text { Identitas } & 110010\end{array}$

Nomor Statistik Madrasah 15.2.03.62.01.001

Alamat

Jl. Arwana No. 04 Blotongan Salatiga 50715 Telp. (0298) 315637

Alamat Web. Miglobalsalatiga.Sch.Id Email Info@

Akreditasi B

Kurikulum Kurikulum Tingkat Satuan Pendidikan

Sistim Pembelajaran Berbasis Komopetensi

Tempat Pembelajaran Indor dan Out Dor Class

Jumlah Siswa $\quad 107$

Pendidik dan Tenaga 20 orang
Kependidikan

Kegiatan Pembiasaan

Pagi

Ikrar, Pidato, Hafalan Dora Dora Harian, Hafalan Surat-Surat Pendek,Tadarus Al-Qur dan Salat Dhuha

Kegiatan Pembiasaan

Siang

Jama'ah Salat Dhuhur

Kegiatan Ekstra Kurikuler

Pramuka, Seni Rupa,TIK, Seni Tari, Bela Diri, dan Khot Al-quran 
Tujuan Kegiatan Ekstra Kegiatan Pramuka

Kurikuler

Untuk menanamkan kesadaran berbangsa dan bernegara

Untuk melatih kemandirian

Untuk melatih hidup bersahaja

Untuk melatih keterampilan

Kegiatan Komputer

Untuk memperkenalkan tehnologi dan informasi

Untuk melatih ketrampilan dibidang tehnologi informatika dan komputer

Kegiatan Bela Diri

Untuk mendidik murid memiliki akhlakul karimah

Untuk melatih murid memiliki kepercayaan pada diri sendiri

Untuk melatih murid memiliki keterampilan beladiri

Untuk menjaga agar kesehatan murid tetap terjaga

Untuk melatih murid agar bersikap disiplinan

Kegiatan Seni Rupa

Untuk menyalurkan minat dan bakat serta ketrampilan murid

Untuk mendidik murid agar menghargai seni dan budaya

Membudayakan seni islami

Kegiatan Seni Tari

Untuk menyalurkan minat dan bakat serta ketrampilan

Untuk mendidik menghargai seni dan budaya

Membudayakan seni islami

Kegiatan Dokter Kecil

Untuk menanamkan agar siswa memiliki kesadaran dan kepedulian terhadap kesehatan pribadi dan lingkungan

Untuk melatih siswa agar mampu memberikan pertolongan pertama pada sesama 
Visi Madrasah

Indikator Visi

Misi Madrasah
Terwujudnya pribadi taat beribadah, berakhlaqul karimah dan berprestasi

Terwujudnya pribadi yang mampu membaca dan memahami Alqur'an dengan baik dan benar

Terwujudnya pribadi yang tekun melaksanakan ibadah wajib maupun sunnah

Terwujudnya pribadi yang santun dalam bertutur dan berperilaku

Terwujudnya pribadi yang unggul dalam prestasi akademik dan non akademik sebagai bekal melanjutkan ke pendidikan yang lebih tinggi dan atau hidup mandiri.

Terwujudnya pribadi yang memiliki ketrampilan sosial dan keagamaan

Terwujudnya umat yang memiliki jiwa kepemimpinan

Menyelenggarakan pendidikan yang berkualitas dalam pencapaian prestasi akademik dan non akademik

Mewujudkan pembelajaran dan pembiasaan dalam mempelajari Alqur'an dan menjalankan ajaran agama Islam Ala Ahlussunnah Wal jama'ah.

Mewujudkan pembentukan karakter Islami yang mampu mengaktualisasikan diri dalam masyarakat.

Meningkatkan pengetahuan dan profesionalisme tenaga kependidikan sesuai dengan perkembangan dunia pendidikan

Menyelenggarakan tata kelola madrasah yang efektif, efisien, transparan dan akuntabel 
Tujuan Madrasah

Mengoptimalkan proses pembelajaran dengan menggunakan pendekatan Pembelajaran Aktif , Inovatif, Kreatif, Efektif, dan Menyenangkan

Mengembangkan potensi akademik, minat dan bakat siswa melalui layanan bimbingan konseling dan kegiatan ekstra kurikuler

Membiasakan perilaku Islami terhadap lingkungan

Meningkatkan prestasi akademik siswa dengan nilai rata-rata 7,5

Meningkatkan prestasi non akademik siswa di bidang seni dan olehraga melalui kejuaraan dan kompetisi.

Menanamkan jiwa kepemimpinan melalui penerapan kedisiplinan sehari-hari

\section{Peningkatan dan Pengembangan Kompetensi Guru}

Sebagaitenaga profesional, guru dituntut memvalidasi ilmunya, baik melalui belajar sendiri maupun melalui program pembinaan dan pengembangan yang dilembagakan oleh pemerintah. Pembinaan merupakan upaya peningkatan profesionalisme guru yang dapat dilakukan melalui kegiatan seminar, pelatihan, dan pendidikan. Pembinaan guru dilakukan dalam kerangka pembinaan profesi dan karier (Masnur Muslih,2007:69). Pembinaan profesi guru meliputi pembinaan kompetensi pedagogik, kompetensi kepribadian, kompetensi profesional, dan kompetensi sosial. Pembinaan karier sebagaimana dimaksud meliputi penugasan dan promosi.

Seperti disebutkan di atas, aktivitas pengembangan profesi guru bersifat terus-menerus, tiada henti, dan tidak ada titik puncak kemampuan profesional yang benar-benar final(Nugroho Susanto,2000:38). Di sinilah esensi bahwa guru harus menjalani proses Pengembangan Profesional Berkelanjutan (PPB) atau continuing professional development (CPD). Pembinaan dan pengembangan profesi guru dilaksanakan atas dasar prinsip umum 
dan prinsip khusus. Prinsip umum antara lain seperti berikut ini. Pertama, diselenggarakan secara demokratis dan berkeadilan serta tidak diskriminatif dengan menjunjung tinggi hak asasi manusia, nilai keagamaan, nilai kultural, dan kemajemukan bangsa. Kedua, diselenggarakan sebagai satu kesatuan yang sistemik dengan sistem terbuka dan multimakna. Ketiga, diselenggarakan sebagai suatu proses pembudayaan dan pemberdayaan guru yang berlangsung sepanjang hayat. Keempat, diselenggarakan dengan memberi keteladanan, membangun kemauan, dan mengembangkan kreativitas guru dalam proses pembelajaran. Kelima, diselenggarakan dengan memberdayakan semua komponen masyarakat melalui peran serta dalam penyelenggaraan dan pengendalian mutu layanan pendidikan.

Prinsip khusus atau operasional pengembangan profesi disajikan seperti berikut ini. Pertama, ilmiah, dimana keseluruhan materi dan kegiatan yang menjadi muatan dalam kompetensi dan indikator harus benar dan dapat dipertanggungjawabkan secara keilmuan. Kedua, relevan, dimana rumusannya berorientasi pada tugas pokok dan fungsi guru sebagai pendidik profesional, yakni memiliki kompetensi kepribadian, sosial, profesional dan pedagogik. Ketiga, sistematis, dimana setiap komponen dalam kompetensi jabatan guru berhubungan secara fungsional dalam mencapai kompetensi. Keempat, konsisten, dimana adanya hubungan yang ajeg dan taat asas antara kompetensi dan indikator. Kelima, aktual dan kontekstual yakni rumusan kompetensi dan indikator dapat mengikuti perkembangan Ipteks. Keenam, fleksibel, dimana rumusan kompetensi dan indikator dapat berubah sesuai dengan kebutuhan dan perkembangan jaman. Ketujuh, demokratis, dimana setiap guru memiliki hak dan peluang yang sama untuk diberdayakan melalui proses pembinaan dan pengembangan profesionalitasnya, baik secara individual maupun institusional. Kedelapan, obyektif, dimana setiap guru dibina dan dikembangkan profesi dan karirnya dengan mengacu kepada hasil penilaian yang dilaksanakan berdasarkan indikator-indikator terukur dari kompetensi profesinya. Kesembilan, komprehensif, dimana setiap guru dibina dan dikembangkan profesi dan karirnya untuk mencapai kompetensi profesi dan kinerja yang bermutu dalam memberikan layanan pendidikan dalam rangka 
membangun generasi yang memiliki pengetahuan, memiliki kemampuan atau kompetensi, mampu menjadi dirinya sendiri, dan bisa menjalani hidup bersama orang lain. Kesepuluh, memandirikan, dimana setiap guru secara terus menerus diberdayakan untuk mampu meningkatkan kompetensinya secara bereksinambungan, sehingga memiliki kemandirian profesional dalam melaksanakan tugas dan fungsi profesinya. Kesebelas, profesional, dimana pembinaan dan pengembangan profesi dan karir guru dilaksanakan dengan mengedepankan nilai-nilai profesionalitas. Keduabelas, bertahap, dimana pembinaan dan pengembangan profesi dan karir guru dilaksanakan secara bertahap agar guru benar-benar mencapai puncak profesionalitas. Ketigabelas, berjenjang, dimana pembinaan dan pengembangan profesi dan karir guru dilaksanakan secara berjenjang berdasarkan jenjang kompetensi atau tingkat kesulitan kompetensi yang ada pada standar kompetensi. Keempatbelas, berkelanjutan, dimana pembinaan dan pengembangan profesi dan karir guru dilaksanakan secara berkelanjutan karena perkembangan ilmu pengetahuan, teknologi dan seni serta adanya kebutuhan penyegaran kompetensi guru. Kelimabelas, akuntabel, dimana pembinaan dan pengembangan profesi dan karir guru dapat dipertanggung-jawabkan secara transparan kepada publik. Keenambelas, efektif, dimana pelaksanaan pembinaan dan pengembangan profesi dan karir guru harus mampu memberikan informasi yang bisa digunakan sebagai dasar dalam pengambilan keputusan yang tepat oleh pihak-pihak yang terkait dalam pembinaan dan pengembangan profesi dan karir lebih lanjut dalam upaya peningkatan kompetensi dan kinerja guru. Ketujubbelas, efisien, dimana pelaksanaan pembinaan dan pengembangan profesi dan karir guru harus didasari atas pertimbangan penggunaan sumberdaya seminimal mungkin untuk mendapatkan hasil yang optimal.

Pembinaan dan pengembangan profesi dan karir guru, termasuk juga tenaga kependidikan pada umumnya, dilaksanakan melalui berbagai strategi dalam bentuk pendidikan dan pelatihan (diklat) maupun bukan diklat, antara lain seperti berikut ini. 
1. Pendidikan dan Pelatihan (Diklat)

a. In-house training (IHT). Pelatihan dalam bentuk IHT adalah pelatihan yang dilaksanakan secara internal di kelompok kerja guru, sekolah atau tempat lain yang ditetapkan untuk menyelenggarakan pelatihan. Strategi pembinaan melalui IHT dilakukan berdasarkan pemikiran bahwa sebagian kemampuan dalam meningkatkan kompetensi dan karir guru tidak harus dilakukan secara eksternal, tetapi dapat dilakukan oleh guru yang memiliki kompetensi yang belum dimiliki oleh guru lain, dengan strategi ini diharapkan dapat lebih menghemat waktu dan biaya.

b. Program magang. Program magang adalah pelatihan yang dilaksanakan di dunia kerja atau industri yang relevan dalam rangka meningkatkan kompetensi profesional guru. Program magang ini diperuntukkan bagi guru dan dapat dilakukan selama periode tertentu, misalnya, magang di sekolah tertentu untuk belajar manajemen kelas atau manajemen sekolah yang efektif. Program magang dipilih sebagai alternatif pembinaan dengan alasan bahwa keterampilan tertentu yang memerlukan pengalaman nyata.

c. Kemitraan sekolah. Pelatihan melalui kemitraan sekolah dapat dilaksanakan antara sekolah yang baik dengan yang kurang baik, antara sekolah negeri dengan sekolah swasta, dan sebagainya. Jadi, pelaksanaannya dapat dilakukan di sekolah atau di tempat mitra sekolah. Pembinaan lewat mitra sekolah diperlukan dengan alasan bahwa beberapa keunikan atau kelebihan yang dimiliki mitra, misalnya, di bidang manajemen sekolah atau manajemen kelas.

d. Belajarjarakjauh. Pelatihan melalui belajar jarak jauh dapat dilaksanakan tanpa menghadirkan instruktur dan peserta pelatihan dalam satu tempat tertentu, melainkan dengan sistem pelatihan melalui internet dan sejenisnya. Pembinaan lewat belajar jarak jauh dilakukan dengan pertimbangan bahwa tidak semua guru terutama di daerah terpencil dapat mengikuti pelatihan di tempat-tempat pembinaan yang ditunjuk seperti di ibu kota kabupaten atau di provinsi. 
e. Pelatihan berjenjang dan pelatihan khusus. Pelatihan jenis ini dilaksanakan di lembaga-lembaga pelatihan yang diberi wewenang, dimana program disusun secara berjenjang mulai dari jenjang dasar, menengah, lanjut dan tinggi. Jenjang pelatihan disusun berdasarkan tingkat kesulitan dan jenis kompetensi. Pelatihan khusus (spesialisasi) disediakan berdasarkan kebutuhan khusus atau disebabkan adanya perkembangan baru dalam keilmuan tertentu.

f. Kursus singkat di perguruan tinggi atau lembaga pendidikan lainnya. Kursus singkat dimaksudkan untuk melatih meningkatkan kemampuan guru dalam beberapa kemampuan seperti kemampuan melakukan penelitian tindakan kelas, menyusun karya ilmiah, merencanakan, melaksanakan dan mengevaluasi pembelajaran, dan lainlain sebagainya.

g. Pembinaan internal oleb sekolah. Pembinaan internal ini dilaksanakan oleh kepala sekolah dan guru-guru yang memiliki kewenangan membina, melalui rapat dinas, rotasi tugas mengajar, pemberian tugas-tugas internal tambahan, diskusi dengan rekan sejawat dan sejenisnya.

b. Pendidikan lanjut. Pembinaan profesi guru melalui pendidikanlanjutjuga merupakanalternatifbagipeningkatan kualifikasi dan kompetensi guru. Pengikutsertaan guru dalam pendidikan lanjut ini dapat dilaksanakan dengan memberikan tugas belajar baik di dalam maupun di luar negeri bagi guru yang berprestasi. Pelaksanaan pendidikan lanjut ini akan menghasilkan guru-guru pembina yang dapat membantu guru-guru lain dalam upaya pengembangan profesi.

2. Kegiatan selain Pendidikan dan Pelatihan (Diklat)

a. Diskusi masalah-masalah pendidikan. Diskusi ini diselenggarakan secara berkala dengan topik diskusi sesuai dengan masalah yang dialami di sekolah. Melalui diskusi berkala diharapkan para guru dapat memecahkan masalah 
yang dihadapi berkaitan dengan proses pembelajaran di sekolah ataupun masalah peningkatan kompetensi dan pengembangan karirnya.

b. Seminar. Pengikutsertaan guru di dalam kegiatan seminar dan pembinaan publikasi ilmiah juga dapat menjadi model pembinaan berkelanjutan bagi peningkatan keprofesian guru. Kegiatan ini memberikan peluang kepada guru untuk berinteraksi secara ilmiah dengan kolega seprofesinya berkaitan dengan hal-hal terkini dalam upaya peningkatan kualitas pendidikan.

c. Workshop. Workshop dilakukan untuk menghasilkan produk yang bermanfaat bagi pembelajaran, peningkatan kompetensi maupun pengembangan karirnya. Workshop dapat dilakukan misalnya dalam kegiatan menyusun KTSP, analisis kurikulum, pengembangan silabus, penulisan RPP, dan sebagainya.

d. Penelitian. Penelitian dapat dilakukan guru dalam bentuk penelitian tindakan kelas, penelitian eksperimen ataupun jenis yang lain dalam rangka peningkatan mutu pembelajaran.

e. Penulisan buku/bahan ajar. Bahan ajar yang ditulis guru dapat berbentuk diktat, buku pelajaran ataupun buku dalam bidang pendidikan.

f. Pembuatan media pembelajaran. Media pembelajaran yang dibuat guru dapat berbentuk alat peraga, alat praktikum sederhana, maupun bahan ajar elektronik atau animasi pembelajaran.

g. Pembuatan karya teknologi/karya seni. Karya teknologi/ seni yang dibuat guru dapat berupa karya yang bermanfaat untuk masyarakat atau kegiatan pendidikan serta karya seni yang memiliki nilai estetika yang diakui oleh masyarakat. 


\section{Prestasi Ujian Nasional (UN) MI Ma'arif Global}

Prestasi Ujian Nasional (UN) MI Ma'arif Global tiga tahun terakhir ini khususnya selalu menunjukkan hasil yang jauh dari membanggakan (baca:peringkat ke-5 dari bawah dengan jumlah $\mathrm{SD} / \mathrm{MI}=112$ ). Secara teoritis-normatif, terdapat banyak hal yang dapat digunakan untuk mendukung pernyataan tersebut.

1. Pengaruh Pendidikan dan Pembelajaran Unggul

Seseorang secara genetis telah lahir dengan suatu organisme yang disebut inteligensi yang bersumber dari otaknya. Struktur otak telah ditentukan secara genetis, namun berfungsinya otak tersebut menjadi kemampuan umum yang disebut inteligensi, sangat dipengaruhi oleh interaksi dengan lingkungannya (Semiawan, C, 1997).

2. Perkembangan dan Pengukuran Otak

Penggunaan sistem kompleks dari proses pengelolaan otak ini sebenarnya sangat menentukan inteligensi maupun kepribadian dan kualitas kehidupan yang dialami seorang manusia, serta kualitas manusia itu sendiri. Untuk meningkatkan kecerdasan anak, maka produksi sel neuroglial, yaitu sel khusus yang mengelilingi sel neuron yang merupakan unit dasar otak, dapat ditingkatkan melalui berbagai stimulus yang menambah aktivitas antara sel neuron (synaptic activity) dan memungkinkan akselerasi proses berfikir(Thompsn, Berger, dan Berry,1980 dalam Clark,1986).

3. Kecerdasan (Inteligensi) Emosional

Prestasi belajar di sekolah sangat dipengaruhi oleh kemampuan umum peserta didik yang diukur oleh Intelligence Quetient(IQ). Intelligence Quetient(IQ) yang tinggi meramalkan suskses terhadap prestasi belajar. Namun IQ yang tinggi ternyata tidak menjamin sukses di masyarakat (Segal, 1997:14). Kajian teoritis tersebut di atas, apabila diproyeksikan ke MI Ma'arif Global sungguh tidak diketemukan nilai-nilai praxisnya; yang demikian ini karena hampir semua peserta didik berada pada batas kemampuan "tengah ke bawah". 


\section{Kesimpulan}

Guru profesional adalah guru yang dalam melaksanakan tugas pokok dan fungsinya bersifat otonom, menguasai kompetensi secara komprehensif, dan daya intelektual tinggi, memiliki kemampuan untuk selalu mengembangkan kompetensi pedagogik dan profesional dengan melakukan profesionalisasi diri, memotivasi diri, memiliki disiplin diri, mengevaluasi diri, taat asas pada kode etik, memiliki kesadarandiri, melakukan hubungan yang efektif, berempati tinggi, dan menjadi pembelajar yang terus melakukan pengembangandiri. Pembinaan dan pengembangan profesi dan karir guru, termasuk juga tenaga kependidikan pada umumnya, dapat dilaksanakan baik melalui pendidikan dan pelatihan (diklat) maupun bukan diklat.

\section{Daftar Pustaka}

Bafadhal, Ibrahim. 2009. Peningkatan Profesionalisme Guru, Jakarta, Bumi Aksara

B. Uno, Hamzah. 2011. Perencanaan Pembelajaran, Jakarta, Bumi Aksara

Danim, Sudarman. 2011. Pengembangan Profesi Guru, Bandung, Prenada Media

Depdiknas. 2002. Pendekatan Kontekstual. Jakarta

Hamalik, Oemar, 2010. Pendidikan Guru Berdasarkan Pendekatan Kompetensi, Bandung, Bumi Aksara

$$
\text { 2010. Perencanaan Pengajaran Berdasarkan }
$$

Pendekatan Sistem, Bandung, Bumi Aksara

Majid, Abdul, 2010, Perencanaan Pembelajaran, Bandung, Remaja RosdaKarya

Mulyasa, E. 2003. Menjadi Kepala Sekolah Profesional, Bandung: PT Remaja Rosdakarya. Rosdakarya. 
Musfah, Jejen. 2011. Peningkatan Kompetensi Guru, Bandung, Prenada Media

Muslih, Masnur, 2007. Sertifikasi Guru Menuju Profesionalisme Pendidik, Bandung, Bumi Aksara

Nasution, S. 2008. Mengajar dengan Sukses, Bandung, Bumi Aksara 2011. Proses Belajar Mengajar, Bandung, Bumi Aksara

Semiawan, Cony. 1982. Prinsip dan Teknik Pengukuran dan Penilaian di dalam Dunia Pendidikan. Jakarta: Mutiara.

Usman, Mohamad Uzer,. 1995. Menjadi Guru Profesional. Bandung: Remaja Rosda Karya.

Peraturan Menteri Pendidikan Nasional RI Nomor 16 Talmn 2007 tentang Standar Kualifikasi Akademik dan Kompetensi Guru.

Rosyada, Dede, 2007. Paradigma Pendidikan Demokratis, Jakarta, Prenada Media

Sanjaya, Wina. 2011. Kurikulum dan Pembelajaran. Bandung, Prenada Media

2011. Perencanaan dan Desain Sistem Pembelajaran, Bandung, Prenada Media

2010, Pembelajaran Dalam Implementasi Kurikulum Berbasis Kompetensi, Jakarta, Prenada Media

Sudjana, Nana, dan Ibrahim, R. 2000. Penelitian dan Penilaian Pendidikan. Bandung: Sinar Baru, Algesindo.

Susanto, Nugroho. 2000. Pelaksanaan Penilaian Jabatan Fungsional Guru. Bandung: Universitas Pendidikan Indonesia.

Tilaar, H. A. R. 1997. Manajemen Pendidikan Nasional. Bandung: Remaja Rosdakarya. 
Taharuddin, Toto. 2002. Kinerja Profesional Guru. Bandung: Universitas Pendidikan Indonesia

Trianto. 2011. Mendesain Model Pembelajaran Inovatif-Progresif, Bandung, Prenada Media 